\title{
DASHBOARDING INFORMATION SYSTEMS FOR THE EDUCATION SECTOR: APLICATION AND METHODOLOGIES
}

\author{
Henderi ${ }^{1}$ \\ Untung Raharjda ${ }^{2}$ \\ Qory Oktisa Aulia ${ }^{3}$ \\ Muhamad Hendri ${ }^{4}$ \\ e-mail : henderi@pribadiraharja.com,untung@pribadiraharja.com, \\ Qory@pribadiraharja.com, hendri@pribadirarahaj.com
}

Diterima : 25 Mei 2011/ Disetujui : 28 Juni 2011

\begin{abstract}
Information technology (IT) has been able to made improve the effectiveness, efficiency, competitiveness, and support the activities of managerial organizations (including educational institutions). This paper discusses the methodology and dashboarding information systems (DIS) application for the education sector as a model of performance measurement and performance evaluation for information systems of the organization in the form of keys performance indicators (KPI). The DIS applications was developed using the methodology of data URL and existng database on other systems as a data warehouse. In the implementation, the DIS applications built using PHP programming language to create front-office applications as interfaces, and software fusionchart as graphics applications. For provide a graphical display and interactive visualization and strong, made the DIS application also uses the eXtensible Markup Language (XML). In order to obtain valid results, DIS applications have been tested to measure the KPI performance on the field of Higher Education Academic Raharja as a DIS performed research and development. The final results of testing showed that the DIS can pull data from the respository preparations of existing data, displaying information that is critical in dashboarding, facilitate the monitoring process, see the picture of an institution's performance in real time, and can meet the information needs of the leaders of the education sector institutions in
\end{abstract}

1. Dosen Jurusan Teknik Informatika, STMIK Raharja

J1. Jend Sudirman No. 40 Modern Cikokol-Tangerang Telp. 5529692

2. Dosen Jurusan Sistem Informasi, STMIK Raharja

J1. Jend Sudirman No. 40 Modern Cikokol-Tangerang Telp. 5529692

3. Mahasiswa Jurusan Sistem Informasi, STMIK Raharja

J1. Jend Sudirman No. 40 Modern Cikokol-Tangerang Telp. 5529692

4. Mahasiswa Jurusan Teknik Informatika, AMIK Raharja Informatika

J1. Jend Sudirman No. 40 Modern Cikokol-Tangerang Telp. 5529692 
conducting measurement of performance against KPI achievements organization. The DIS applications is also able to make changes to performance information through data visualization techniques in the form of dashboarding, on line, and able to apply the principles and workings of e-leadership, early warning, self-monitoring, and constant reminding.

Key words: Dashboarding, early warning, self monitoring, constant reminding

\section{ABSTRAKSI}

Teknologi informasi (TI) telah mampu meningkatkan efektivitas, efisiensi, daya saing, dan mendukung kegiatan manajerial organisasi (termasuk institusi pendidikan). Paper ini membahas metodologi dan aplikasi dashboarding information system (DIS) untuk institusi sektor pendidikan sebagai model sistem informasi pengukuran dan evaluasi capaian kinerja organisasi dalam bentuk key performance indicator (KPI). Aplikasi DIS dikembangkan menggunakan metodologi data URL dan database yang sudah ada pada sistem yang lain sebagai data warehouse. Dalam implementasinya, aplikasi DIS dibangun menggunakan bahasa pemrograman PHP untuk membuat aplikasi front office sebagai interface, dan software fusionchart sebagai aplikasi pembuat grafik. Untuk memberikan tampilan grafik dan visualisasi yang interaktif dan kuat, aplikasi DIS yang dibuat juga menggunakan eXtensible Markup Language (XML). Agar mendapatkan hasil yang sahih, aplikasi DIS telah diuji coba untuk mengukur kinerja KPI dibidang akademik pada Perguruan Tinggi Raharja sebagai tempat pengembangan dan penelitian DIS dilakukan. Hasil akhir pengujian menunjukan bahwa DIS dapat menarik olahan data dari respository data yang sudah ada, menampilkan informasi yang bersifat critical dalam bentuk dashboarding, memudahkan proses pemantauan, melihat gambaran kinerja institusi secara real time, dan dapat memenuhi kebutuhan informasi para pemimpin institusi sektor pendidikan dalam melakukan pengukuran terhadap capaian kinerja KPI organisasinya. Aplikasi DIS pada penelitian ini juga mampu melakukan perubahan performansi informasi melalui teknik visualisasi data dalam bentuk dashboarding, on line, dan mampu menerapkan prinsip dan cara kerja e-leadership, early warning, self monitoring, dan constant reminding.

Kata kunci : Dashboarding, early warning, self monitoring, constant reminding

\section{PENDAHULUAN}

Sektor pendidikan menggunakan teknologi informasi (TI) untuk mendukung dan meningkatkan efektivitas dan efisiensi. Tidak berbeda dengan sektor industri, organisasi nirlaba, dan instansi pemerintahan. Melalui penerapan TI, sektor pendidikan (selanjutnya disebut institusi pendidikan) dapat menghasilkan produk dan jasa yang berkualitas tinggi, bersifat global, dan berdaya saing tinggi. Bahkan pada tingkat tertentu, pemanfaatan TI secara optimal dapat meningkatkan standar, kualitas dan 
kemampuan kompetitif institusi pendidikan, dan dapat mendukung pelaksanaan fungsi dan tugas manajerial.

Walau demikian, masih banyak para pemimpin institusi pendidikan yang belum dapat memanfaatkan TI secara optimal dalam fungsi manajerialnya. Salah satu penyebabnya karena belum ada aplikasi TI yang dikembangkan khusus untuk pemimpin institusi pendidikan dalam bentuk aplikasi dashboarding information system (DIS) sebagimana fungsi dashboarding system pada berbagai kendaraan yang sangat strategis bagi driver. Aplikasi DIS merupakan sistem yang menampilkan informasi dalam bentuk dashboard yang sangat penting bagi pemimpin institusi pendidikan (yang dapat di-analogikan sebagai driver organisasi) dalam mengendalikan dan membawa organisasinya mencapai sasaran, tujuan, visi dan misi yang telah ditetapkan.

Permasalahan yang dihadapi oleh pemimpin institusi sektor pendidikan tersebut hendak dipecahkan dalam penelitian ini. Selain itu, berdasarkan hasil penelitian awal terhadap beberapa output sistem informasi diketahui bahwa sebagian besar output (laporan) sistem infomasi yang ada saat ini (khususnya pada sektor pendidikan) ditampilkan dalam bentuk tabel dan data angka. Belum dalam bentuk dashboard. Penampilan informasi seperti ini memunculkan kendala bagi para pemimpin institusi sektor pendidikan karena membutuhkan waktu lebih lama dalam memahaminya, dan belum bersifat real time. Proses existing tersebut juga menghasilkan banyak data angka yang sedemikian overwhelming, menjadikan data dan informasi susah untuk dipantau, dan memberikan kesulitan dalam menarik olahan data dan informasi yang bersifat critical.

Pada sisi lain, para pemimpin sektor pendidikan membutuhkan akses terhadap informasi strategis, dan informasi yang menyoroti anomali-anomali tertentu dari informasi tersebut. Karena itu, penelitian ini bertujuan untuk mengembangkan metodologi, membuat dan menguji aplikasi dashboarding information system (DIS) pada sektor pendidikan sebagai usulan solusi yang efektif untuk memecahkan permasalahan dan kendala yang tersebut.

Pengembangan aplikasi DIS pada penelitian ini dibuat menggunakan metodologi data URL methode. Metodologi data URL adalah sebuah metode yang digunakan untuk mengembangkan sistem informasi yang menggunakan respository data dan database sudah ada sebelumnya [1]. Metodologi URL juga dipilih karena penampilan visualisasi data pada aplikasi DIS yang dibuat menggunakan software FusionChart yang ditanamkan pada skrip pemrograman menggunakan bahasa php. 


\section{HASIL DAN PEMBAHASAN}

\subsection{Konsep DIS dan Pengembangannya}

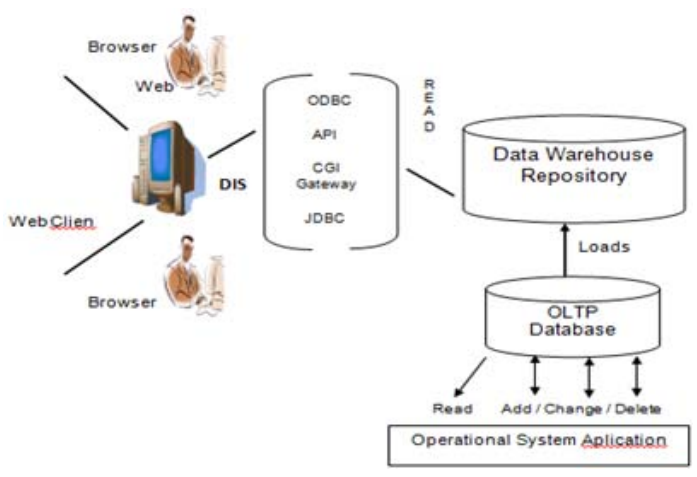

Gambar 1. Skema Information Retrieval DIS

Gambar satu merupakan skema penempatan aplikasi DIS yang hendak dikembangkan pada penelitian ini. Berdasarkan gambar satu tersebut, aplikasi DIS sektor pendidikan yang dikembangkan pada penelitian ini merupakan sebuah aplikasi interface yang berfungsi sebagai front office system. Karena itu, aplikasi DIS dikembangkan sedemikian rupa sehingga dapat diakses dari terminal mana saja yang terhubung dengan sistem utama institusi pendidikan. Aplikasi DIS berinteraksi dengan sistem server dan data respository utama/data warehouse institusi (lihat gambar 1). Metodologi dan aplikasi DIS pada institusi pendidikan ini dikembangkan dengan maksud untuk memudahkan proses monitoring, melihat gambaran, dan memenuhi kebutuhan informasi para pemimpin institusi pendidikan dengan melakukan perubahan performansi informasi melalui teknik visualisasi data. Penerapannya dapat membantu pelaksanaan fungsi manajerial pemimpin institusi pendidikan, yaitu melakukan monitoring dan evaluasi terhadap kinerja organisasi.

Aplikasi DIS ini terinspirasi dari aplikasi dashboard yang ada pada berbagai kendaraan (motor, mobil, pesawat, dan lainnya). Karenanya dashboard pada penelitian ini adalah suatu model antarmuka sistem informasi yang dianalogikan seperti dashboard sebuah mobil yang mudah untuk dipelajari dan sangat strategis bagi driver. Menurut ejaan Bahasa Indonesia yang disempurnakan dashboard ditulis dengan dasbor, yang berarti papan penunjuk.

Dalam penerapannya pada aplikasi DIS, dashboarding information menggunakan teknik visualisasi data, yaitu tekni konversi data ke dalam format visual 
sehingga karakteristik dari data dan relasi di antara item data atau atribut dapat di analisis dan dilaporkan [2]. Teknik visualisasi data ini dimaksudkan untuk memudahkan user (people) untuk menangkap konsep dari data yang di tampilkan karena pada dasarnya user lebih mudah mengartikan sebuah gambar daripada teks yang menjelaskan tentang makna dari gambar tersebut [3].

Penyajian dan visualisasi data yang baik dan benar serta sesuai dengan kebutuhan akan memberikan nilai informasi yang lebih bagi penggunaannya. Karenanya aplikasi DIS dapat menjadi suatu solusi untuk menangani masalah visualisasi data. Aplikasi DIS (seperti halnya dashboard lainnya) mempunyai fungsi dalam membantu mengidentifikasi elemen-elemen kunci dalam sebuah organisasi sehingga sangat berguna bagi organisasi untuk mengetahui kinerjanya berdasarkan KPI (Key Performance Indicator) yang telah ditentukan. Melalui tampilan yang eksekutif, instan dan ringkas, aplikasi DIS akan memfasilitasi para pihak yang berkepentingan dalam pengambilan keputusan, melakukan prediksi untuk performance organisasi dimasa yang akan datang, serta menentukan langkah taktis maupun strategis berdasarkan data dan informasi secara terkini. Dengan desain yang baik, DIS juga dapat dibuat untuk membantu para pemimpin institusi pendidikan (dan lainnya) dalam mengidentifikasi tren, pola dan anomali kinerja organisasi dan anomali data sehingga pada akhirnya dapat membantu dalam pengambilan keputusan yang efektif.

\subsection{Key Performace Indicator (KPI)}

Key performance indicator (KPI) merupakan ukuran kuantitatif dan kualitatif yang menggambarkan tingkat pencapaian suatu sasaran atau tujuan yang telah ditetapkan [4]. Dalam kerangka manajemen strategis, terdapat bagian perencanaan strategis yang meliputi penentuan visi, misi, tujuan dan sasaran, serta cara mencapai tujuan dan sasaran yang meliputi kebijakan, program dan kegiatan. Selanjutnya rencana strategis tersebut yang akan diukur kinerjanya berdasarkan kebijakan, program dan kegiatan. Pengukuran dilakukan untuk mengetahui tingkat kinerja organisasi dalam mengeksekusi rencana strategis, mencapai tujuan, dan sasaran yang telah ditetapkan.

Dalam menyusun indikator kinerja diperlukan pemahaman yang baik tentang kegiatan proyek, tujuannya, sumber daya yang tersedia, ruang lingkup kegiatan dan saling berhubungan diantara berbagai kegiatan yang dilaksanakan untuk memperoleh hasil, manfaat dan dampak yang diharapkan. Untuk mendapatkan pemahaman dan pencapaian kesepakatan terhadap keterkaitan antar indikator kinerja yang disusun, 
dan mengukur kinerja organisasi dapat ditempuh melalui pendekatan kerangka kerja logis, yang mencakup dan terbagi dalam kelompok indikator, yaitu: indikator masukan (inputs), keluaran (outputs), hasil (outcomes), manfaat (benefits) dan dampak (impacts).

Berdasarkan penjelasan tentang KPI di atas, dan untuk mempermudah pengembangan dan pelaksanaan uji coba sistem, maka pengembangan metodologi dan aplikasi DIS pada sektor pendidikan pada penelitian ini dilakukan untuk mengukur indikator masukan (dosen, sumber belajar, mahasiswa), dan indikator hasil (indek prestasi kumulatif mahasiswa/lulusan) sebagai prototipe.

\subsection{Software Pendukung dan URL Methode}

Salah satu kelebihan dari aplikasi DIS yang akan dikembangkan pada penelitian ini adalah mampu menampilkan data/informasi dalam bentuk dashboarding. Untuk itu, dalam pengembangan aplikasi DIS diperlukan software pendukung yang mampu menampilkan data/informasi dalam bentuk visual. Salah satu software yang memiliki kemapuan menampilan data/informasi dalam bentuk visual adalah software FusionCharts.

Pembuatan aplikasi DIS pada sektor pendidikan dengan yang menggunakan software FusionChart pada penelitian memiliki langkah teknis kurang lebih sama seperti mengembangkan aplikasi menggunakan jpgraph, dimana aplikasi yang dibangun diharuskan untuk mengunduh library yang berisi class-class program. Pemilihan software FusionChart dalam pembuatan aplikasi DIS juga dikarenakan FusionChart dapat digunakan untuk membangun grafik berbasis website yang dapat digabungkan dengan beberapa bahasa pemrograman seperti PHP, ASP, ASP.NET, JSP, Ruby on Rails [3]. Untuk memberikan tampilan grafik yang interaktif dan kuat, FusionChart menggunakan XML (eXtensible Markup Language) sebagai data interface. Dengan XML, FusionChat dapat menampilkan keindahan dari aplikasi Flash untuk membuat diagram yang bagus, interaktif dan visual. Selain itu, FusionChart juga dapat menampilkan berbagai tipe grafik, diantaranya: Column 2D Chart, Column 3D Chart, Line 2D Chart, Pie 3D Chart, Pie 2D Chart, Bar 2D Chart, Area 2D Chart, Doughnut 2D Chart, dan lain-lain.

Selain dapat mendukung grafik berbasis web, dan mempunyai kemampuan menampilkan berbagai bentuk grafik, software FusionChart digunakan karena mampu menampilkan data/informasi menggunakan data URL methode dan XML methode. Mekanisme dan cara kerja data URL methode digambarkan pada gambar dua. 


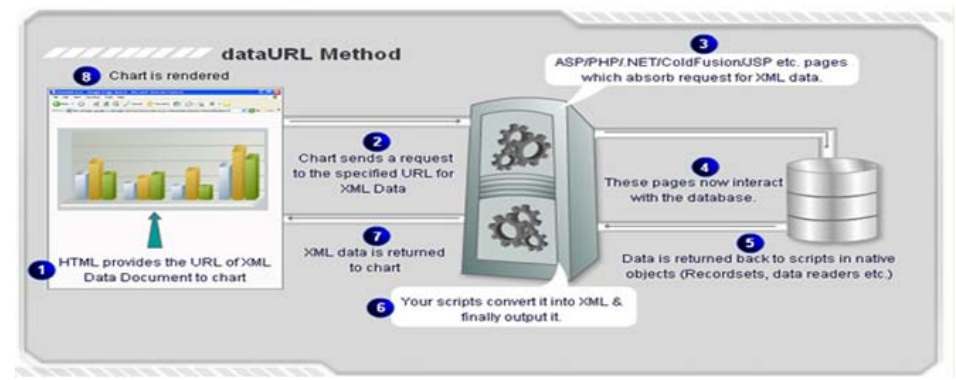

Gambar 2. Skema dan Cara Kerja Data URL Methode

Metodologi data URL (Data URL Methode) yang diilustrasikan pada gambar dua adalah sebuah metode information retrieval yang digunakan pada sebuah sistem informasi yang menggunakan respository data dan database yang sudah ada pada sistem yang lain/sistem sebelumnya. Dalam implementasinya, DIS pada sektor pendidikan pada penelitian ini menggunakan Metodologi data URL karena menggunakan database yang sudah ada di Perguruan Tinggi Raharja sebagai tempat uji coba aplikasi dilakukan.

Berdasarkan gambar dua pula, diketahui bahwa pada Data URL Methode aplikasi hanya memerlukan $U R L$ dari XML data ketika terjadi proses permintaan (request) dari client dan akan direspon oleh server. Selanjutnya data akan ditampilkan ke client komputer dalam bentuk XML Data untuk diubah (render) kedalam tampilan grafik. Sementara untuk memberikan tampilan grafik yang interaktif dan kuat, FusionChart menggunakan XML (eXtensible Markup Language) sebagai data interface sehingga dapat menampilkan keindahan dari aplikasi Flash, membuat diagram yang bagus, interaktif dan visual.

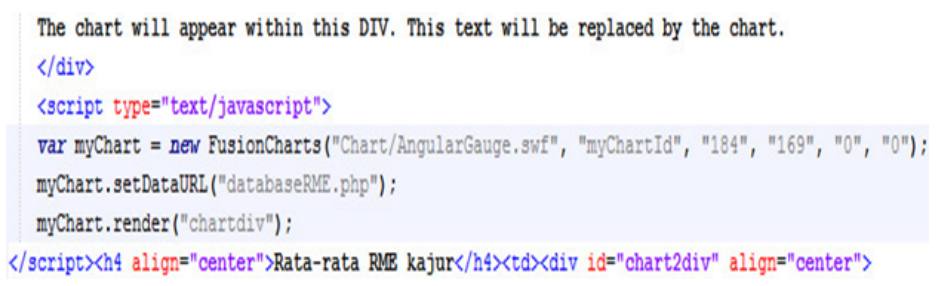

Gambar 3. Contoh skrip PHP untuk melakukan load URL dari XML data

Skrip baris ketiga pada gambar tiga, merupakan potongan fungsi index.php, dimana terlihat bahwa file konten databaseRME.php dan file grafik 
AngularGauge.swf di-request dari client, dan akan mendapat respon dari server, kemudian pada bagian hasilnya akan dirender dalam bentuk grafik pada sebuah web browser. Fungsi ini merupakan implementasi dari data URL methode pada aplikasi DIS untuk sektor pendidikan yang dikembangkan dan diimplementasikan dalam penelitian ini.

Melalui penggunaan metode tersebut, maka data/informasi yang merupakan indikator kinerja organisasi dapat ditampilkan dalam bentuk dashboarding, visual, real time dan on line melalui terminal yang terhubung dengan sistem informasi utama dan data warehouse institusi. Alur logik pengembangan metodologi dan aplikasi DIS pada penelitian digambarkan secara sederhana pada gambar empat. Berdasarkan gambar empat, dapat dilihat bahwa aplikasi DIS mempunyai keunggulan dibandingkan dengan sistem informasi pada umumnya dalam hal menampilkan hasil pengolahan data menjadi informasi yang merupakan indikator kinerja organisasi.

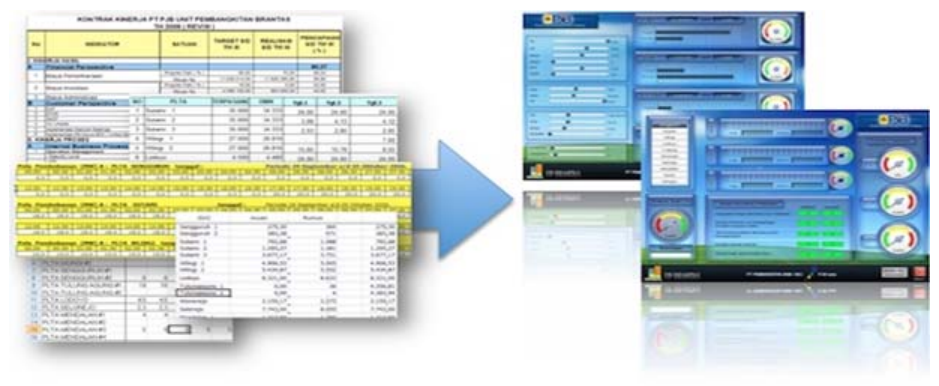

Gambar 4 Output sistem informasi konvensional VS output aplikasi DIS

Output information retrivel dari sistem informasi umumnya ditampilkan dalam bentuk teks dan tabel, sementara pada aplikasi DIS data/informasi dapat ditampilkan dalam bentuk dashboarding information dan visual yang merupakan indikator kinerja organisasi (gambar 4). Terjadi perubahan signifikan dari data yang ditampilkan dalam bentuk table kedalam bentuk dashboard. Disisi lain, rincian terhadap informasi tersebut masih dapat ditampilkan oleh dashboard jika memang diperlukan, sehingga tidak mengurangi nilai dari informasi tersebut.

Aplikasi DIS yang dikembangkan pada penelitian ini juga mempunyai keunggulan dibandingkan dengan sistem pelaporan sistem informasi biasa karena memiliki fitur drill down. Melalui fasilitas fitur dril down, aplikasi DIS mampu melakukan penggalian terhadap data secara factual, hingga ke tingkat root data dan akar masalah. Secara nyata, fitur ini ditampakkan dalam sebuah dashboard, 
misalnya dengan tampaknya indikator berwarna merah atau kuning (penanda peringatan atau waspada) di dashboard. Berikut akan dijelaskan beberapa contoh hasil implementasi dan uji coba aplikasi DIS berbagai indikator capaian kinerja KPI berdasarkan data factual yang ada pada database Perguruan Tinggi Raharja sebagai tempat penelitian dan uji coba dilaksanakan.

\subsection{Dashboading Information System (DIS)}

Pengembangan dan implementasi aplikasi DIS yang dibahas pada penelitian ini secara khusus bertujuan untuk menjawab permasalahan utama pemimpin institusi pada sektor pendidikan khususnya dalam hal memperoleh informasi strategis tentang kinerja institusi dari aspek input dan output (dosen, sumber belajar, mahasiswa) secara real time, on line, dan factual.Dashboarding KPI indek mutu jurusan bisa dilihat dari beberapa indikator, diantaranya adalah indek mutu ketersediaan sumber belajar, indek mutu dosen, indek mutu mahasiswa, dan indek mutu lulusan (gambar 5). Gambar lima merupakan output utama aplikasi DIS yang diterapkan di Perguruan Tinggi Raharja. Aplikasi DIS ini menampilkan indikator kinerja sesuai dengan row data factual yang ada pada database (data warehouse) yang diakses oleh aplikasi DIS.

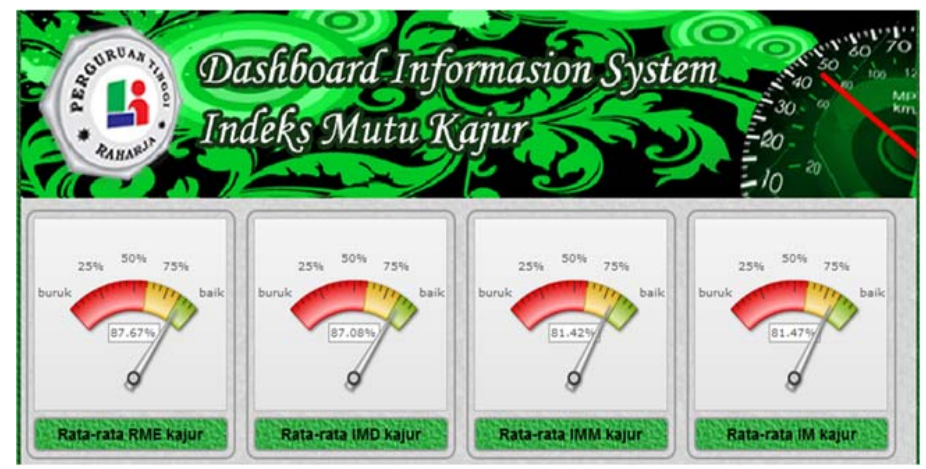

Gambar 5. Main dashboarding aplikasi DIS pada sektor pendidikan (hasil uji coba)

Tampak pada gambar lima, aplikasi DIS dapat menampilkan hasil pengolahan data/informasi tentang indek mutu jurusan dalam bentuk dashboarding. Output aplikasi DIS tersebut menggambarkan indikator tingkat kinerja setiap jurusan di Perguruan Tinggi Raharja (sebagai tempat uji coba sistem DIS dilakukan). Secara nyata, fitur dashboard menampilkan indikator warna kinerja, misalnya: adanya indikator berwarna merah atau kuning pada dashboard (penanda peringatan atau 
waspada), warna kuning berarti tingkat kinerja cukup/hampir mencapai tingkat yang baik (aman), dan warna hijau berarti kinerja berada pada tingkat baik (aman) berdasarkan target indikator yang telah ditentukan sebelumnya. Selain menampilkan dashboard indikator, aplikasi DIS juga menampilkan resume tingkat kinerja dalam bentuk persen (\%). Berdasarkan aoutput DIS pada gambar lima, dapat disimpulkan bahwa dari keempat KPI sebagai indikator kinerja jurusan, yaitu: (1) KPI ketersediaan sumber belajar (panel RME), (2) KPI indek mutu dosen (IMD), (3) KPI indek mutu mahasiswa (IMM), (4) KPI dan indek mutu jurusan (IM) berada pada level baik. Status baik yang dimaksud ditunjukan oleh jarum indikator yang berada pada wilayah warna hijau (jarum berada pada wilayah kanan dashboard). Sementara untuk mengetahui tingkat kinerja jurusan pada setiap indikator cukup dilakukan klik pada teks show data KPI maka DIS akan menampilkan visual data/ informasi KPI setiap jurusan. Selain bentuk indikator, dashboard juga bisa menampilkan beragam jenis grafik sesuai kebutuhan untuk mempermudah pembuatan grafik dashboard sesuai dengan data yang ada, karena data pada setiap perusahaan atau instansi berbeda. Dengan demikian, aplikasi DIS pada penelitian ini merupakan jawaban atas tantangan institusi pendidikan dalam menyediakan informasi untuk menjawab pendapat yang disampaikan oleh Akhmat Guntar [5] bahwa pertumbuhan organisasi memunculkan tantangan dalam menyediakan informasi yang bersifat analytical dan actionable.

\section{a. Dashboading Sumber Belajar (RME)}

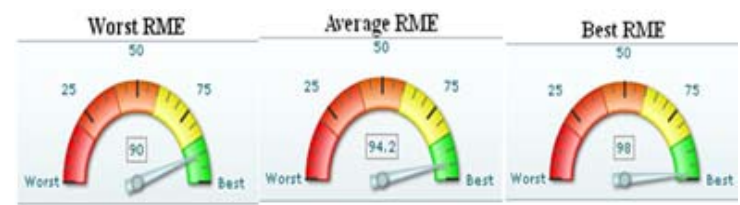

Gambar 6 Dashboarding KPI RME

Status kelengkapan sumber belajar (bahan ajar) dalam bentuk digital dan tersimpan pada respository Raharja Multimedia Edutainment (selanjutnya disebut RME) merupakan salah satu indikator kinerja yang diukur pada aplikasi DIS. Pengukuran terhadap status kelengkapan RME ini dilakukan oleh DIS dan menampilkan hasilnya alam bentuk dashboard seperti pada gambar enam.

Dengan memperhatikan dashboard kinerja KPI RME pada gambar enam, pemimpin institusi pendidikan dapat dengan cepat dan tepat mengetahui status kinerja kelengkapan sumber belajar institusinya. Pada saat uji coba dilakukan, aplikasi DIS menampilkan dashboard tingkat kinerja KPI RME berada pada status baik dan 
telah mencapai target kinerja yang telah ditetapkan (jarum penunjuk kinerja pada dashboard ada pada wilayah warna hijau, dan rata-rata status kelengkapan RME ada pada angka 94,2). Output dan fungsi aplikasi DIS ini terbukti dapat menjawab kebutuhan pemimpin institusi pendidikan untuk mendapatkan informasi strategis dan analistik tentang tingkat kinerja organisasi, dan dapat digunakan dalam mengambil keputusan berdasarkan data/informasi factual. Hasil uji coba aplikasi DIS pada penelitian ini mendukung dan memperkuat hasil penelitian yang dilakukan oleh Henderi, dkk [6], yang menyatakan bahwa pengukuran kinerja enterprise (termasuk sektor pendidikan) dapat dilakukan menggunakan TI dengan cara mengukur tingkat capaian KPI yang telah ditetapkan oleh organisasi.

\section{a. Dashboarding Indek Mutu Dosen (IMD)}

KPI kedua yang diukur dan ditampilkan sebagai tingkat kinerja institusi sektor pendidikan (tinggi) pada aplikasi DIS adalah indek mutu dosen (IMD). Indek mutu dosen merupakan gambaran kinerja dosen secara menyeluruh dan merupakan gabungan dari performance indicator (PI) kelengkapan sumber belajar, kedisiplinan dosen dalam melaksanakan pembelajaran (kehadiran), tingkat kepuasan mahasiswa terhadap dosen (melalui kuisioner), melaksanakan penelitian, dan melaksanakan pengabdian pada masyarakat. Output dashboarding pada aplikasi DIS mengenai KPI kedua (indek mutu dosen/IMD) tampak pada gambar tujuh.

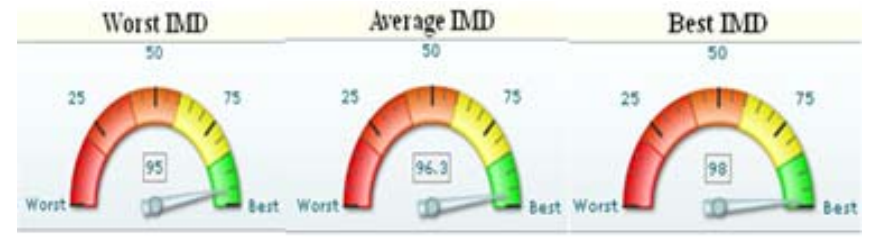

Gambar 7. Dashboarding KPI Indek Mutu Dosen/IMD

Berdasarkan tampilan dashboard tentang status tingkat kinerja KPI kedua (indek mutu dosen/IMD) pada gambar tujuh, pemimpin institusi pendidikan dapat mengetahui, memonitor, mengevaluasi, dan mengambil keputusan yang berhubungan dengan tingkat kinerja dosen dengan cepat dan tepat. Tampilan dashboarding information pada gambar tujuh tersebut dapat dinyatakan sebagai suatu pengembangan fungsi sistem informasi yang pernah dikembangkan oleh Rahardja Untung, dkk [7] yang dapat berfungsi sebagai early warning, self monitoring, dan constant reminding sistem bagi pemimpin organisasi. 


\section{b. Dashboarding IPK Mahasiswa Aktif}

KPI yang ketiga pada DIS dalam penelitian ini adalah dashboarding information tentang indek prestasi kumulatif (IPK) mahasiswa. Berdasarkan hasil implementasi dan uji coba, tampilan dashboard KPI ketiga yang dihasilkan oleh DIS tampak pada gambar delapan.

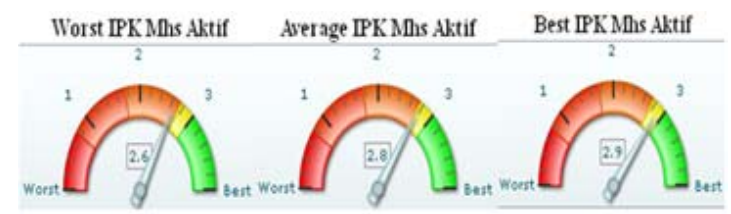

Gambar 8 Dashboarding KPI IPK mahasiswa

Tingkat kinerja KPI IPK mahasiswa (gambar delapan) merupakan dashboarding status IPK mahasiswa aktif berdasarkan data sebenarnya pada respository data warehouse yang diakses aplikasi DIS pada saat uji coba dilakukan. Karena itu, DIS mampu menghasilkan informasi yang bersifat faktual (berdasarkan row data factual), real time, dan ditampilkan secara on line. Tampilan dashboarding kinerja KPI IPK mahasiswa tersebut selanjutnya secara otomatis akan menyesuaikan diri ketika terjadi perubahan IPK pada sistem data warehouse institusi pendidikan (misalnya ketika nilai mahasiswa pada akhir setiap semester telah meng-update data IPK yang ada pada data warehouse).

Berdasarkan kenyataan tersebut, aplikasi DIS yang dihasilkan pada penelitian ini pada prinsipnya juga merupakan bentuk perluasan implementasi konsep dan cara kerja data mining pada sistem informasi untuk memenuhi kebutuhan informasi yang bersifat strategis bagi pemimpin organisasi. Dengan demikian metodologi dan aplikasi DIS pada sektor pendidikan ini juga merupakan sebuah inovasi dalam menerapkan teknik clustering data seperti yang disampaikan oleh Taryana Acep [8], karena aplikasi DIS pada penelitian ini juga mempengaruhi konfigurasi lapisan bisnis lojik dan database lojik, dan membutuhkan pengaturan DBMS yang terpasang pada master server sehingga dapat melakukan sinkronisasi data di seluruh server. Dengan demikian tampilan aplikasi DIS tentang kinerja KPI akan selalu terjaga konsistensinya dimanapun aplikasi DIS diakses oleh para pemimpin institusi pendidikan melalui sebuah node yang terkoneksi dengan sever pusat.

\section{c. Dashboarding IPK Lulusan}

IPK lulusan juga merupakan indikator kinerja institusi sektor pendidikan. Karena itu aplikasi DIS yang dikembangkan pada penelitian ini juga mempunyai 
kemampuan untuk mengukur dan menampilkan dashboarding indikator KPI IPK lulusan (gambar 9).

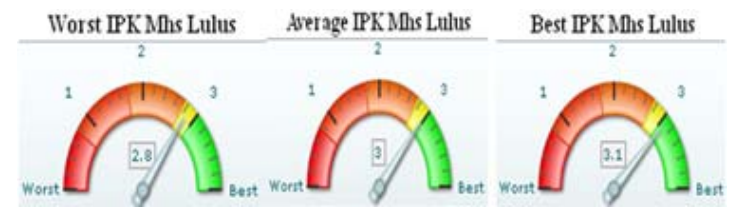

Gambar 9 Dashboarding KPI IPK Lulusan

Dashboarding KPI IPK lulusan yang ada pada gambar sembilan merupakan indikator kinerja institusi sektor pendidikan yang menunjukan hasil proses pembelajaran (aspek output) yang telah dilaksanakan kepada peserta didik. Dengan memperhatikan dashboading KPI IPK Lulusan pada gambar sembilan, para pemimpin institusi pendidikan dapat mengetahui mutu lulusannya dari aspek IPK setiap saat, dan mengambil keputusan untuk meningkatkannya. Output aplikasi DIS pada gambar sembilan tersebut membuktikan bahwa pengembangan metodologi dan aplikasi DIS pada penelitian ini dapat dipakai untuk menyempurnakan model sistem pendukung keputusan yang dikembangkan oleh Nurhaeni Yeni, dkk [9] untuk memperlancar pelaksanaan monitoring dan evaluasi kinerja perguruan tinggi dan peningkatan kinerja dosen yang melibatkan lima pelaku utama, yaitu: dosen, mahasiswa, quality assurance, direktorat akademik, dan kepala program studi.

\section{d. Dashboarding KPI Mahasiswa Tidak Aktif}

Performance institusi pendidikan juga dapat diukur dan dilihat dari aspek jumlah mahasiswa yang cuti kuliah. Karenanya, aplikasi DIS yang dikembangkan pada penelitian ini juga menetapkan jumlah mahasiswa yang cuti merupakan salah satu KPI yang diukur dan ditampilkan dalam sebuah dashboarding (gambar 10).

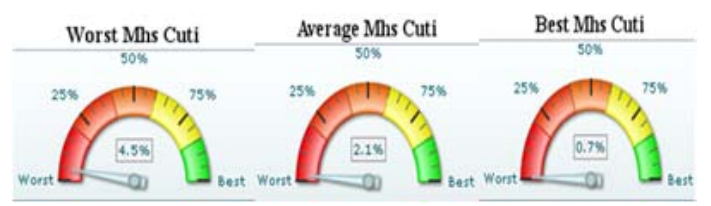

Gambar 10. Dashboarding KPI Mahasiswa Cuti

Gambar sepuluh yang dihasilkan oleh aplikasi DIS pada penelitian ini pada prinsipnya juga merupakan sebuah kemajuan dalam mengembangkan dan mengimplementasikan sebuah aplikasi berbasis data warehouse dan data mining sebagai pengukur kinerja enterprise. Karena output pada aplikasi DIS pada 
penelitian ini merupakan salah satu jawaban atas rekomendasi hasil penelitian tentang sistem pengukur kinerja yang dilakukan henderi, dkk [6] bahwa perlu dilakukan pengembangan aplikasi komputer sebagai tool pengukur kinerja enterprise yang lebih efektif, yang mampu menampilkan hasil pengukuran kinerja dalam bentuk dashboard sehingga dapat mudah dibaca dan dipahami oleh eksekutif dan user. Aplikasi DIS pada penelitian bisa menjawab rekomendasi tersebut karena output sudah ditampilkan dalam bentuk dashboard, colour code, mudah dibaca dan dipahami, dan dapat berubah secara real time berdasarkan data yang di-capture oleh sistem back office.

\section{KESIMPULAN}

Hasil akhir pengujian dan implementasi menunjukan bahwa dashboard information system (DIS) dapat menghasilkan dan menampilkan informasi dalam bentuk dashboarding, visual, real time, dan on line sehingga mampu menerapkan prinsip early warning, self monitoring, dan constant reminding. Jenis dan tipe informasi yang dihasilkan oleh DIS merupakan bentuk ringkasan dan bersifat critical, strategis, sehingga mampu membantu para pemimpin institusi sektor pendidikan dalam memimpin organisasinya dan menerapkan prinsip dan cara kerja e-leadership dalam mencapai sasaran, tujuan, visi dan misi yang telah ditetapkan.

\section{REKOMENDASI}

Penelitian lebih lanjut diperlukan agar penerapan konsep dan implementasi aplikasi dashboard information system (DIS) dapat dikembangkan secara lebih mendalam, dibuat sesuai dengan best practice enterprise, dan aplikasi DIS semakin banyak digunakan untuk mendukung penerapan konsep dan cara kerja e-leadership oleh para esekutif berbagai organisasi (termasuk sektor pendidikan di dalamnya). Dengan diharapkan semakin banyak dikembangkannya metodologi dan aplikasi DIS untuk meningkatkan peranan TI dalam mencapai sasaran, tujuan, visi dan misi organisasi, khususnya dalam pelaksanaan evaluasi terhadap kinerja organisasi, dan membantu para eksekutif membuat keputusan strategis dan mengendalikan organisasi yang dipimpinnya dengan baik. Pada akhirnya akan semakin banyak aplikasi berbasis komputer yang digunakan sebagai penunjuk indikator kinerja tujuan/target yang ingin dicapai oleh sebuah organisasi agar tidak mengalami kemunduran, bertahan, dan/ atau dapat memenangkan persaingan yang semakin kompetitif dan mengarah kepada digitalization business. 


\section{UCAPAN TERIMA KASIH}

Penelitian ini dibiayai oleh Raharja Enrichment Center (REC) dan telah diuji coba di Perguruan Tinggi Raharja. Untuk itu penulis mengucapkan terima kasih kepada Ketua REC yang telah memberikan bantuan dan dukungannya, dan seluruh jajaran REC juga telah membantu penulis selama melaksanakan penelitian. Penulis juga menyampaikan terimakasih kepada Direktur Perguruan Tinggi dan Ketua REC yang telah mengijinkan penulis menggunakan fasilitas laboratorium selama melakukan penelitian dan uji coba aplikasi DIS ini.

\section{PUSTAKA}

[1] Few, Stephen. (2004). Information Dashboard Design: The Effective Visual Communication of Data. O'Reilly.

[2,3] A. Indri Juwita, A. Elmi, M. Wildan, W. Rini, dan R. Yan. (2009). Teknik Visualisasi Grafik Berbasis Web Di Atas Platform Open Source. http:// localhost80.wordpress.com/2010/11/20/realtime-chart-without-pagerefresh-using-ajax-technique-part-1/, diakses pada tanggal 20 September 2010.

[4] Gaspersz Vincent. (2003). Balance Scorecard dengan Six Sigma untuk Organisasi Bisnis dan Pemerintahan. PT Gramedia Pustaka Utama, Jakarta.

[5] Guntar Akhmad. Stellar Dashboard Data Insight \& Visualisation, http:// akhmadguntar.com/tentang-guntar/stellar-dashboard-data-insightvisualisation.html, diakses pada tanggal 24 Desember 2010.

[6] Henderi, Rahardja Untung, Yusuf Muhamad,(2011). Sistem Data Warehouse dan Data Mining sebagai Pengukur Kinerja Enterprise. Proseding Konferensi Nasional Sistem Informasi (KNSI), hal.738-744. STMIK Potensi Utama, Medan.

[7] Rahardja Untung, Murad Dina Fitria, Chalifatullah.(2008).Periodic Historical System sebagai Evaluasi Strategis dalam Mendukung Pengambilan Keputusan. Creative Communication and Innovative Technologi (CCIT) Journal, 1 (2), 154-164.

[8] Taryana, Acep. (2010). Penerapan Teknik Clustering Basis Data, Study Kasus: Sistem Informasi Akademik Unsoed. Proseding Seminar Nasional Ilmu Komputer, hal. 26-32. Universitas Diponegoro, Semarang.

[9] Yeni Nurhaeni,Henderi.(2010). Model Sistem Pendukung Keputusan untuk monitoring dan Peningkatan Kinerja Dosen, Creative Communication and Innovation Technology (CCIT) Journal, 3 (3), 366-376. 